\title{
Effects of planting dates and potato (Solanum tuberosum L.) genotypes on late blight caused by Phytophthora infestans (Mont.) de Bary epidemics, growth and tuber yields in Southern Ethiopia
}

\author{
Kanko Chuntale Chulda ${ }^{1,2 \star}$, Getachew Gudero Mengesha ${ }^{1,3}$ and Alemayew Wodajo Wotango ${ }^{1,4}$ \\ ${ }^{1}$ Southern Agricultural Research Institute (SARI), Arba Minch Agricultural Research Center (AmARC), P. O. Box 2228, \\ Arba Minch, Ethiopia. \\ ${ }^{2}$ Root and Tuber Crop Research Department (Root and Tuber Breeder), SARI, AmARC, SARI, P.O.BOX. 2228, Arba \\ Minch, Ethiopia. \\ ${ }^{3}$ Crop protection Department (Plant Pathology), SARI, AmARC, SARI, P. O. Box 2228, Arba Minch, Ethiopia. \\ ${ }^{4}$ Pre-Extension Research Department (Crop Pre-Extension research), SARI, AmARC, SARI, P. O. Box 2228, Arba \\ Minch, Ethiopia.
}

*Corresponding author: Email: kankochuntale@gmail.com; Fax (+251) 46881 2001; Tel: (+251) 913764486.

Copyright (@ 2021 Chulda et al. This article remains permanently open access under the terms of the Creative Commons Attribution License 4.0, which permits unrestricted use, distribution, and reproduction in any medium, provided the original work is properly cited.

Received 20th November, 2020; Accepted 20th April, 2021

\begin{abstract}
The study was conducted at Chencha in Southern Ethiopia during the 2018 and 2019 main cropping years to determine the effects of planting dates and potato genotypes on late blight epidemics and yields related traits; as well as identify optimum planting date and potato genotypes which show low levels of late blight severity with high tuber yields under a natural epiphytotic environment. The treatments composed of four potato genotypes (Belete, Gudenie, Jalenie, and local check) and three planting dates (on 10th June, 10th July, and 20th August). The experiment was laid out in a split-plot design with four replications. Planting dates were assigned as the main factor, while the potato genotypes were represented as a sub-plot factor. Average late blight severities of $29.19,35.82$, and $44.70 \%$ were recorded on plants with a planting date of 20th August, 10th July, and 10th June, respectively. Foliar late blight severities of 27.31, 32.45, 38.58, and $47.95 \%$ were recorded on Belete, Gudanie, Jalenie, and local cultivar, respectively. Similarly, the relative area under disease progress curve (AUDPC) of 20.28, 24.93, and 29.31\%-days were recorded on planting dates of 20th August, 10th July, and 10th June, respectively. The highest (19.37\%-days) and lowest (31.32\%-days) values of AUDPC were recorded from the genotypes Belete and local cultivar, respectively. Results also showed that the highest single tuber weight $(87.20$ g) and total tuber yield $\left(13.40 \mathrm{t} \mathrm{ha}^{-1}\right)$ were obtained from the genotype Gudenie. Regarding planting dates, the highest single tuber weight $(88.91 \mathrm{~g})$ was recorded from the genotypes planted on 10th June. Whereas the highest total tuber yield $\left(15.77 \mathrm{t} \mathrm{ha}^{-1}\right)$ was obtained from the genotypes planted on 20th August, which was not statistically different from the other planting dates. Overall, considering disease development, tuber yield potential, and effectiveness in disease reduction, planting of Gudenie on 20th August was relatively effective for potato late blight management as compared to other genotypes and planting dates. Therefore, this could be suggested for the study area and similar agro-ecological conditions to enhance sustainable potato production.
\end{abstract}

Keywords: AUDPC, late blight, planting dates, potato genotypes, severities, total tuber yield.

\section{INTRODUCTION}

Potato (Solanum tubersum L.) is one of the most economically important root crops grown worldwide, especially in Ethiopia (CSA, 2018; FAOSTAT, 2018). It is an excellent cash and food security crop in the highlands of Ethiopia (Tesfaye et al., 2013; CSA, 2018). The crop can provide high-quality products per unit area with a 
short cycle of life than major cereal and pulse crops in the highland areas of the country. The crop is grown by more than 3.6 million households on areas of $143,288.45$ hectares and produced a total of $2,013,406.00$ tons (CSA, 2018). However, despite its importance and potentials in the country, the production is constrained by different biotic, including diseases, insect pests, weeds (Semira, 2016) and abiotic factors, as well as inadequate high yielding varieties with disease resistance, low inputs and poor cultural practice among other limitations (Adane et al., 2010). Consequently, the national average productivity of potato $\left(14.01 \mathrm{t} \mathrm{ha}^{-1}\right)(\mathrm{CSA}, 2018)$ is very low compared with the world's average yield of $23.04 \mathrm{t} \mathrm{ha}^{-1}$ (FAOSTAT, 2018). According to the 2018 cropping season annual report of the District's Bureau of Agricultural Office, at Chencha, the productivity of potato is $9.01 \mathrm{t} \mathrm{ha}^{-1}$, which is far below the national average yields of the crop.

Among the primary diseases that were major cause of low productivity of potatoes in the main planting season is the late blight. Late blight of potato caused by Phytophthora infestans (Mont.) de Bary is the most crucial production constraint and accountable for low productivity per unit area in potato production worldwide wherein area known with moderate temperature, high rainfall and relative humidity within the country (de Barry, 1876; Hijmans et al., 2000; Agrios, 2005; Yoshida et al., 2013). The disease affects both the foliage and tubers of potato under field conditions even during storage (Schumann and D'Arcy, 2000; Agrios, 2005). The disease was first experienced in Europe during the 1840s where it led to the devastating of great Irish potato epidemics, which resulted in famine, for more than 1.5 million people (Bourke, 1991). In Ethiopia, it is also one of the most responsible agents for substantial yield reduction in all potato growing areas (Guchi, 2015; Semira, 2016). Yield losses due to late blight ranging from negligible to complete failure depending on the severity of the infection. Potato yield losses of 65 to $100 \%$ have been reported in highly severe potato cultivars in Ethiopia (Kassa and Hiskias, 1996; Mekonen et al., 2011; Tsedaley, 2014).

The success of $P$. infestans as a pathogen originates from its effective asexual and sexual life cycles (Agrios, 2005). The life cycle of $P$. infestans begins when the sporangia, spore-producing structures, land on moistened host leaf or other parts. The optimal temperature for sporangia germination by zoospores production is 12 to $13^{\circ} \mathrm{C}$ and for germ tube production is $24^{\circ} \mathrm{C}$ directly in the host tissue. This process takes place between 8 to 48 hours under favorable environmental conditions, high rainfall (> $20 \mathrm{~mm}$ per day), optimum temperature (20 to 25 ${ }^{\circ} \mathrm{C}$ ), and high relative humidity (70 to $90 \%$ ). The minimum temperature for sporangia germination is as low as 2 to $3^{\circ} \mathrm{C}$, while the maximum may as high as 24 to $30^{\circ} \mathrm{C}$ (Singh and Bhattachyra, 1990). Rapid invasion of the host tissue by $P$. infestans occurs under a relative humidity of 70 to $80 \%$ with a temperature between 13 and $14^{\circ} \mathrm{C}$ for two days or more. The rainy, humid, foggy, or cool conditions service late blight infection, development, and dispersal. The pathogen overwinters on tubers, dumps, volunteers, and alternate hosts (de Barry, 1876; Agrios, 2005; Razukas et al., 2008). Survival in infected tubers also leads to aerial sporangia development. Aerial sporangia development and distribution is of great importance since a very small proportion of infected tubers have the potential to cause epidemics when seedlings grow on the field. Distribution of the sporangia from infected to healthy plants within and/or across the field occurs by wind, rain splashes, and farm equipment (Arora, 1990). During favorable environmental conditions, yield loss due to late blight can be speedy and unstoppable if preventative measures are not used (Agrios, 2005; Stone, 2014).

Several management options have been reported for late blight, including cultural practice (use of disease-free tubers, adequate ventilation and avoidance of pilling during storage, removal of infected plant debris, the burial of diseased debris by deep plowing, eradication of alternate hosts, crop rotations, and prevention of excessive use of nitrogen fertilizer (Agrios, 2005; Stone, 2014), cultivation of resistant genotypes (Forbes and Jarvis, 1994; McGrath et al., 2014), biological control (Roy et al., 1991) and fungicide measures as a foliar application (Kassa et al., 2002; Agrios, 2005) and integrated disease management, including cultural plus fungicide spray, host resistance plus fungicide spray or combination of cultural, host resistance and fungicide spray (Kirk et al., 2005; Mekonen et al., 2011; Getachew et al., 2018). As stated, several studies have been conducted through various methods to manage late blight. Indeed, the difficulty of the disease is further complicated with the collapse of the resistance gene in promising potato genotypes. The management of late blight had been through the use of fungicides highly effective. Although they have been highly effective, they have potential to contaminate the environment and may even pose health hazard on users (Green et al., 1990; Wastie, 1991; Brent and Hollomon, 2007; Hussain et al., 2009). Against this background, practically applicable and sustainable approaches for the management of late blight through manipulation of planting date with economically safe levels are desired.

Late blight being a crucial disease in the study areas causing considerable yield losses, an adequate research has not been carrying out on the management of the late blight, especially combinations of planting dates and potato genotypes during the main cropping seasons. However, there were little reports on literature on the management of late blight disease through adjustment of planting time (Bekele and Gebre-Medhin, 2000; Abraham et al., 2015). However, most investigations have concentrated on the incorporation of fungicides with rates, types, spray frequency, or alterations (Kassa et al., 2002; Mekonen et al., 2011; Ayda, 2015; Getachew et al., 2019). Thus, there is an urgent need for empirical data on the effects of combinations of planting dates and potato genotypes on the severity of late blight and yield potentials 
of the genotypes at different planting dates during the main cropping season. Bekele and Gebre-Medhin (2000), Singh and Pundhir (2012), Gaire et al. (2014) and Abraham et al. (2015) reported that the occurrence and severity of late blight were significantly affected by planting dates and the response of the potato genotypes. Therefore, these are the possible factors that need to be addressed in association with the occurrence and severity of late blight with yield potentials in potato production systems.

Cultivating at different planting dates may be changed in such a way that the susceptible stage of plant growth does not coincide with the favorable environmental conditions for disease initiation and development of epidemics (Valbhav and Pundhir, 2012; Satya et al., 2018). Planting dates could also be associated with the need for fluctuation of daily temperature and relative humidity at which interrupting the life cycle and inactive and retarding of the development of $P$. infestans during the growing periods. Late blight life cycle and epidemic development are strongly affected by the day temperatures and other weather variables during the cropping season (de Barry, 1876; Agrios, 2005; Razukas et al., 2008). Also, the performance of potato genotypes may vary with planting dates concerning late blight reaction (Bekele and GebreMedhin, 2000; Abraham et al., 2015; Getachew et al., 2019). Given potato genotypes have a different levels of resistance to late blight, they may respond with lower severity at early or medium or late planting time, even moderately or highly susceptible to the disease may escape through manipulations of planting dates. A potato genotype that reacts to lower late blight severity with high yield potential at any of the planting dates will be preferred by the farming communities. Consequently, inquiries on the collective role of planting dates and potato genotypes for the management of late blight may generate information appropriate for use as a practical component of integrated late blight management strategies, which has not yet been in the study areas during the main cropping season. With these backgrounds, this research was conducted to determine the effects of planting dates and potato genotypes on late blight severity and growth and tuber yields related traits; as well as identify optimum planting date and potato genotype which show low levels of late blight severity with high tuber yields under the natural epiphytotic environment.

\section{MATERIALS AND METHOD}

\section{Description of the study site}

The experiment was conducted at the Chencha substation of Arba Minch Agricultural Research Center in Southern Ethiopia during the 2018 and 2019 main cropping years. The station is geographically positioned at $06^{\circ} 17^{\prime} 55^{\prime \prime} \mathrm{N}$ and $37^{\circ} 33^{\prime}$ '04" $E$ and at an altitude of 3005 meters above sea levels. The area was selected based on the regular occurrence of late blight during potato production period.
Potato was cultivated in both short and long rainy seasons during the production year. The majority of potato cultivation was done during the short rainy season, March to May, than long rainy season (July to November), which constituted 75 and $25 \%$ production coverage, respectively. Chencha is characterized by a bimodal rainfall pattern where the short rainy season start from March to May, while the long rainy season start from July to November. The mean annual total rainfall and temperature of the area for the last ten years was $1171.81 \mathrm{~mm}$ and $15.67{ }^{\circ} \mathrm{C}$, respectively. Detailed descriptions of weather conditions of the 2018 and 2019 cropping years are illustrated in Table 1. According to the report of MoANR and EATA (2016), the characteristic feature of the site's soil is strongly acidic, salt free, low $\mathrm{CaCO}_{3}(0.12 \%)$, low cataion exchange capacity (18.75 Cmolc $\left.\mathrm{kg}^{-1}\right)$, low total nitrogen $(0.05 \%)$, very low available phosphorous $(0.06 \mathrm{ml} \mathrm{kg}-1)$ and low organic matter contents at a range of 0.25 to $1.05 \%$ and sandyloam textural class.

\section{Treatments, experimental design and field management}

The experiment was conducted in an open environment to ensure late blight incidents under natural infection. Combinations of four potato genotypes (Belete, Gudenie, Jallene and local cultivar) and three planting dates (on 10th June (early), 10th July (medium), and 20th August (late) during the planting period) were used as treatment. The previous potato genotypes present in the study areas exhibited different levels of resistance to late blight. Belete, Gudanie, Jallenie (MoA, 2012; 2013), and local cultivar are represented as resistance, moderately resistance/tolerant, susceptible, and highly susceptible, respectively. Potato seeds were obtained from Holeta Agricultural Research Centre (HARC), Ethiopian Institute of Agricultural Research, and Farmer field within the study area (local cultivar).

In the study, the treatments consist of four potato genotypes and three planting dates that were randomly arranged in a split-plot design in four replicates. The main plot represented planting dates, while the potato genotypes were assigned to subplots. Each plot composed of four rows, and the size of the unit plot was laid out at $2.6 \mathrm{~m}$ in width and $3 \mathrm{~m}$ long. Inter and intra-row spacing of 75 and $30 \mathrm{~cm}$ were maintained for planting of the genotypes, respectively. The sprouting tubers ranges from 35 to $55 \mathrm{~mm}$ in diameter were planted manually in rows on the assigned dates, as suggested by Mohammad et al. (2013). Each row within the plots consisted of 10 plants. The space between plots and replications was $1 \mathrm{~m}$ and $1.5 \mathrm{~m}$, respectively. Fertilizers were applied at the rates of $236 \mathrm{~kg} \mathrm{ha}^{-1} \mathrm{NPS}, 144 \mathrm{~kg} \mathrm{ha}^{-1} \mathrm{~N}$-fertilizer, and 125 $\mathrm{kg} \mathrm{ha}^{-1}$ Muriate of Potash (MoP). The whole rates of NPS, MoP and half of the N-fertilizer were applied at the time of planting. The remaining half of the $\mathrm{N}$-fertilizer was applied during the flowering time. Weeding, cultivation, and ridging practices were conducted according to recommendation for the crop, Irish potato (MoA, 2012 \& 2013). 
Table 1. Monthly mean minimum and maximum temperature and rainfall at Chencha in Southern Ethiopia during 2018 and 2019 cropping seasons.

\begin{tabular}{|c|c|c|c|c|c|c|c|c|c|c|c|c|c|}
\hline Year & Weather variable & Jan & Feb & Mar & Apr & May & Jun & Jul & Aug & Sep & Oct & Nov & Dec \\
\hline \multirow[t]{4}{*}{2018} & Maximum $\left({ }^{\circ} \mathrm{C}\right)$ & 24.13 & 20.55 & 25.32 & 24.11 & 20.52 & 19.88 & 20.39 & 20.69 & 21.67 & 21.72 & 23.37 & 24.13 \\
\hline & Minimum $\left({ }^{\circ} \mathrm{C}\right)$ & 15.39 & 10.13 & 19.45 & 13.87 & 10.92 & 10.80 & 10.06 & 10.34 & 10.43 & 10.32 & 11.59 & 17.12 \\
\hline & Rainfall (mm) & 3.30 & 44.40 & 66.60 & 226.20 & 242.00 & 194.80 & 159.40 & 150.40 & 94.40 & 84.20 & 101.90 & 4.50 \\
\hline & $\mathrm{RH}(\%)$ & 49.29 & 62.77 & 74.01 & 79.91 & 67.58 & 74.22 & 79.57 & 69.14 & 54.90 & 56.13 & 55.24 & 53.13 \\
\hline \multirow[t]{4}{*}{2019} & Maximum $\left({ }^{\circ} \mathrm{C}\right)$ & 23.47 & 19.00 & 25.22 & 23.96 & 20.00 & 20.04 & 19.66 & 19.33 & 20.71 & 22.45 & 23.55 & 24.06 \\
\hline & Minimum $\left({ }^{\circ} \mathrm{C}\right)$ & 14.52 & 10.05 & 18.50 & 12.43 & 10.08 & 10.06 & 11.88 & 11.04 & 10.05 & 14.02 & 15.89 & 16.99 \\
\hline & Rainfall (mm) & 7.01 & 26.21 & 67.05 & 252.31 & 229.09 & 207.65 & 187.20 & 139.89 & 98.90 & 75.11 & 97.28 & 3.54 \\
\hline & $\mathrm{RH}(\%)$ & 48.51 & 66.63 & 71.71 & 71.90 & 70.50 & 77.93 & 77.62 & 69.81 & 59.70 & 59.54 & 49.13 & 41.57 \\
\hline
\end{tabular}

Source: National Meteorological Agency at Hawassa Branch (2019). $\mathrm{RH}=$ Relative humidity.

\section{Data collection and analysis}

\section{Disease assessment}

Data were collected on the severity of late blight at weekly intervals with effects from 36 and 41 (for 10 June), 40 and 43 (for 10 July), and 47 and 47 (for 20 August) days after planting (DAP) during the 2018 and 2019 cropping seasons, respectively. Ten randomly pre-tagged potato plants from the two central rows of each plot were used for disease severity assessments and a total of six (in 2018) and seven (in 2019) assessments were monitored until the genotypes attained physiologically maturity.

Disease severity was measured using a 1 to 9 rating scale described by Heinfnings (1978), where 1 = No visible symptom of late blight, 2 = Late blight is presented with maximum of 10 affected leaves per plant covering up to $5 \%$ leaf area, $3=$ Plants seem to be healthy, but necrotic can be easily observed and covered up to 15\%; there are no more than 20 affected leaves per plant, $4=$ Late blight is easily observed on the plants, and about $25 \%$ of the leaf area is affected by infection, $5=$ Plants look green, but each one is affected by the pathogen, lower leaves are necrotic, and about $50 \%$ of the leaf area is destroyed, $6=$ Plants look green with brown spots, and about $75 \%$ of the leaf area is affected and leaves in the middle of the plant are destroyed, $7=$ Only upper leaves are green and most of leaves are affected and many stems have external necrotic $(90 \%$ of aboveground part of the plant is affected), $8=$ Plants look brown, few upper leaves are green and most of the stems are hardly affected or dead $(97.50 \%$ of above ground part of the plant is affected), and $9=$ Leaves and stems are destroyed (100\% of aboveground part of the plant is affected). Then, the severity scores were transformed into percentage severity index (PSI) following the formula suggested by Wheeler (1969) hereafter.

$$
\text { PSI }=\frac{\text { Sum of numerical ratings }}{\text { No. of plants scored } \mathrm{x} \text { maximum score on scale }} \times 100
$$

The area under disease progress curve (AUDPC) was calculated from PSI values assessed at different days for each plot using the formula suggested by Campbell and Madden (1990) hereafter.

$$
\text { AUDPC }=\sum_{i=1}^{n-1} 0.5\left(X_{i}+X_{i+1}\right)\left(t_{i-1}-t_{i}\right)
$$

Where: $X_{i}=$ percentage of disease severity index (PSI) of disease at $i^{\text {th }}$ assessment; $t_{i}=$ time of the ith assessment in days from the first assessment date; and $\mathrm{n}=$ total number of disease assessments.

The duration of disease assessment was not the same for each epidemic period in the two cropping years, and consequently, AUDPC values were standardized (rAUDPC) through dividing the values by the total duration $\left(t_{n}-t_{1}\right)$ of the epidemic periods following the procedure described by Campbell and Madden (1990). The epidemic periods were 35 and 42 (for 10 June and 10 July) and 35 and 45 (for 20 August) days for the 2018 and 2019 cropping years, respectively.

\section{Crop parameters}

The two central rows of each plot, excluding the border rows, were used for the determination of 
phenological parameters (days to $50 \%$ emergence $(50 \%$ DoE), days to $50 \%$ flowering (50\% DoF), and days to $90 \%$ maturity $(90 \% \mathrm{DoM}))$, growth (plant height $(\mathrm{PH}$ in $\mathrm{cm})$ and number of branches per plant (NBP)), and tuber yield and yield-related parameters (number of marketable tubers per plant (NMTP), number of unmarketable tubers per plant (NUMT), the weight of marketable tubers per plant (WMTP in $\mathrm{kg}$ ), weight of unmarketable tubers per plant (WUMTP in $\mathrm{kg}$ ), tuber yield per plot (TYP in $\mathrm{kg}$ ), total tuber yield (TTY in t ha-1), single tuber weight (STW in g), tuber length $(T L$ in $\mathrm{cm}$ ) and tuber diameter (TD in $\mathrm{cm})$ ). The aforementioned parameters were computed from five randomly selected plants within the two central rows, and the mean values were used for analysis.

Days to $50 \%$ emergence, $50 \%$ flowering, and $90 \%$ maturity were considered on the bases of a number of days from planting to $50 \%$ of the plants in a plot emerged, $50 \%$ plants in a plot flowered and at least one flower per plant was opened and $90 \%$ of the plants in each plot turned their leaves to yellow, respectively. Plant height is measured from ground level to the tip of the main stem at physiological maturity and expressed in $\mathrm{cm}$, while numbers of branches per plant were counted from five randomly selected plants within the plot at physiological maturity. The numbers of marketable and unmarketable tubers per plant were determined based on tubers weighing 80 to $300 \mathrm{~g}$ or diameter of 20 to $60 \mathrm{~mm}$, and less than $80 \mathrm{~g}$ or diameter less than $20 \mathrm{~mm}$, respectively. Total tuber yield (marketable and unmarketable) per plot was measured from total harvested tubers from the two central rows. Single tuber weight was measured from randomly sampled five tubers obtained from marketable tubers of each plot. Tuber diameter and length were determined by measuring the widest and longest point of tubers, respectively, on randomly selected five marketable tubers using a vernier caliper.

\section{Data analysis}

Data on phenological, growth, and yield-related traits and disease scores were analyzed using the analysis of variance (ANOVA) to determine the treatment effects. The two years had considered as the different environments owing to the variation in weather conditions during the study periods. The F-test was employed to test the heterogeneity of the error variance following the procedure suggested by Gomez and Gomez (1984). The data were not analyzed independently because cropping years, planting dates, and potato genotypes were fixed factors in the ANOVA, and due to these conditions and homogeneity of variances (interactions of planting date $x$ potato genotype $x$ year) as tested following the F-test procedure, the data were combined for analysis, replication were analyzed as a random factor. Mean separations was carried out using Fishers protected least significance difference (LSD) at a $5 \%$ probability levels. The data analyses were performed using the general linear model procedure of the SAS software version 9.3 (SAS, 2014). The following model for the split-plot design had used.

$\mathrm{Y}_{\mathrm{ijk}}=\mu+\alpha_{i}+\beta_{j}+\gamma_{k}+(\alpha \beta)_{i j}+(\alpha \gamma)_{i k}+\varepsilon_{i j k}$

Where: $i=1,2 \ldots$ planting date, $j=1,2 \ldots$ potato genotype, and $k=1,2 \ldots$ number of replication, $\mu=$ the overall mean effects, $\alpha_{i}=$ the effects of $\mathrm{i}^{\text {th }}$ level of planting date (Main plot factor, $\mathrm{i}=1$ to 3$), \beta_{j}=$ the effects of block, $\gamma_{k}=$ the effects of the $j^{\text {th }}$ level of potato genotype (Subplot factor, $\mathrm{j}=1$ to 4 ), $(\alpha \beta)_{i j}=$ the interaction effects of planting date and block, $(\alpha \gamma)_{i k}=$ the interaction effects of planting date and potato genotype (error for Main plot), and $\varepsilon_{i j k}=$ the experimental error (error for subplot).

\section{RESULTS AND DISCUSSION}

\section{Combined analysis of variance for the studied parameters}

The mean square results obtained from the combined ANOVA showed that there was significant variation among the treatments evaluated for most of the studied parameters. However, the parameters such as NMTP, WMTP, TYP, and TTY for the main plot factors and $50 \%$ DoE and TD for subplot factors exhibited no significant differences. The significant variation among the main plot factors and the subplot factors displayed various levels of significance at $(p \leq 0.01$ to $<0.05)$. However, no interaction ( $p>0.05$ ) effects was observed between main plot factors and the subplot factors except for PSIf, AUDPC, 90\% DoM, and NUMTP, which exhibited significant interaction effects ( $p \leq 0.01$ to $<0.05$ ) for planting dates as well as the potato genotypes (Table 2). The difference in mean square values (highest or lowest) for the main plot and subplot factors might be the tested treatments for the studied crop and disease parameters responded differently for the potato genotypes planted at different planting dates during the growing periods.

\section{Late blight severity and relative area under disease progress curve}

During the experiment, the disease was first appeared on Jallenie and local cultivar in both cropping seasons. The first appearance of disease symptoms were 46 and 47 days for both cropping seasons, respectively. This were maximum days noted from potato genotypes planted on 20th August. Conversely, the minimum number of days to the first appearance of disease symptom (36 and 38 days for the two cropping seasons) was registered from potato genotypes planted on 10th June. This phenomenon might be due to higher accumulations of inocula obtained from short rain season production of potato and daily optimum temperature, high amount of rainfall with high relative humidity during the growing periods in June, which might 


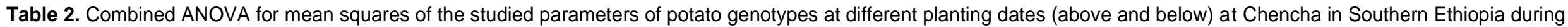
the 2018 and 2019 cropping seasons.

\begin{tabular}{|c|c|c|c|c|c|c|c|c|c|}
\hline Source of variation & DF & $50 \%$ DoE & $50 \%$ DoF & $90 \%$ DoM & $\mathrm{PH}(\mathrm{cm})$ & NBP & NMTP & NUMT & WMTP (kg) \\
\hline Rep & 3 & $7.65^{\star}$ & $16.46^{\star *}$ & $51.13^{\star \star \star}$ & $14.08^{\text {ns }}$ & $3.19^{\text {ns }}$ & $1.87^{\mathrm{ns}}$ & $0.84^{\mathrm{ns}}$ & $0.01^{\mathrm{ns}}$ \\
\hline PD & 2 & $23.01^{* \star *}$ & $39.50^{* * *}$ & $75.78^{* * *}$ & $102.17^{*}$ & $29.14^{* \star *}$ & $2.26^{\text {ns }}$ & $65.51^{* \star *}$ & $0.0003^{n s}$ \\
\hline Error & 6 & 1.94 & 2.61 & 6.20 & 13.58 & 1.66 & 1.038 & 2.89 & 0.003 \\
\hline Var & 3 & $7.01^{*}$ & $57.26^{\star \star \star}$ & $301.35^{\star * \star}$ & $980.82^{\star \star \star}$ & $36.33^{\star \star \star}$ & $31.71^{\star * \star}$ & $154.76^{\star * *}$ & $0.153^{\star \star \star}$ \\
\hline PD*Var & 6 & $2.26 \mathrm{~ns}$ & $0.88^{\mathrm{ns}}$ & $7.96^{\mathrm{ns}}$ & $20.21^{\mathrm{ns}}$ & $0.22^{\text {ns }}$ & $9.12^{* * *}$ & $9.80^{\star}$ & $0.01^{\mathrm{ns}}$ \\
\hline Yr & 1 & $15.84^{* *}$ & $157.59^{\star \star \star}$ & $376.04^{\star \star *}$ & $2051.28^{\star \star \star}$ & $66.67^{\star \star \star}$ & $10.01^{*}$ & $1.26^{\mathrm{ns}}$ & $0.49^{\star \star \star}$ \\
\hline$P D^{*} Y r$ & 2 & $39.78^{\star \star *}$ & $0.00 \mathrm{~ns}$ & $0.39 \mathrm{~ns}$ & $11.52^{\mathrm{ns}}$ & $0.64^{\mathrm{ns}}$ & $51.95^{* * *}$ & $34.39^{* \star *}$ & $0.13^{* \star *}$ \\
\hline $\operatorname{Var}^{*} \mathrm{Yr}$ & 3 & $19.40^{* \star *}$ & $35.54^{* * *}$ & $59.13^{\star \star \star}$ & $169.90^{\star * *}$ & $26.06^{\star \star \star}$ & $16.51^{\star \star \star}$ & $73.09^{* \star *}$ & $0.13^{\star \star \star}$ \\
\hline $\mathrm{PD}^{*} \operatorname{Var}^{*}{ }^{*} \mathrm{r}$ & 6 & $1.09^{n s}$ & $1.07^{*}$ & $4.26^{\mathrm{ns}}$ & $16.06^{\mathrm{ns}}$ & $1.11^{*}$ & $4.62^{*}$ & $18.93^{\star \star \star}$ & $0.002^{*}$ \\
\hline Error & 27 & 1.64 & 3.75 & 12.40 & 23.75 & 2.14 & 1.37 & 1.71 & 0.004 \\
\hline Mean & & 18.68 & 55.47 & 86.56 & 38.85 & 7.79 & 5.95 & 4.55 & 0.26 \\
\hline CV (\%) & & 7.75 & 3.05 & 3.11 & 12.79 & 14.70 & 21.77 & 41.85 & 27.59 \\
\hline
\end{tabular}

Table 2. Contd.

\begin{tabular}{|c|c|c|c|c|c|c|c|c|c|}
\hline Source of variation & DF & WUMTP (kg) & TYP (kg) & TTY (t ha-1) & STW (g) & TL (cm) & TD (cm) & PSIf (\%) & rAUDP (\%day) \\
\hline Rep & 3 & $0.0002^{\text {ns }}$ & $4.66^{\mathrm{ns}}$ & $23.01^{\mathrm{ns}}$ & $619.57^{\mathrm{ns}}$ & $3.12^{*}$ & $0.39^{\text {ns }}$ & $3.31^{\mathrm{ns}}$ & $0.78^{\text {ns }}$ \\
\hline PD & 2 & $0.007^{\star \star \star}$ & $3.82^{\mathrm{ns}}$ & $18.84^{\mathrm{ns}}$ & $7877.15^{\star \star \star}$ & $97.31^{\star \star \star}$ & $13.33^{\star \star \star}$ & $1937.99^{\star \star \star}$ & $652.15^{\star \star \star}$ \\
\hline Error & 6 & 0.0003 & 1.42 & 6.99 & 162.805 & 1.52 & 0.14 & 12.74 & 2.75 \\
\hline Var & 3 & $0.003^{\star \star \star}$ & $51.84^{\star \star \star}$ & $255.99^{\star \star \star}$ & $7934.04^{\star \star \star}$ & $29.45^{\star \star \star}$ & $2.31^{* * *}$ & $1031.57^{\star \star \star}$ & $409.08^{\star \star \star}$ \\
\hline PD*Var & 6 & $0.0004^{\mathrm{ns}}$ & $4.25^{\mathrm{ns}}$ & $20.97^{n s}$ & $214.11^{\mathrm{ns}}$ & $0.57^{\mathrm{ns}}$ & $0.21^{\mathrm{ns}}$ & $43.72^{\mathrm{ns}}$ & $12.97^{\mathrm{ns}}$ \\
\hline Yr & 1 & $0.004^{* \star}$ & $232.27^{\star \star \star}$ & $1147.00^{* \star *}$ & $3992.68^{* \star *}$ & $238.27^{\star \star \star}$ & $82.98^{\star \star \star}$ & $264.44^{\star \star}$ & $436.86^{\star \star \star}$ \\
\hline$P D^{*} Y r$ & 2 & $0.007^{\star \star \star}$ & $65.91^{\star \star \star}$ & $325.49^{\star \star \star}$ & $629.53^{\text {ns }}$ & $46.02^{\star \star \star}$ & $28.82^{\star \star \star}$ & $134.74^{\star}$ & $48.42^{\star}$ \\
\hline $\operatorname{Var}^{*} Y r$ & 3 & $0.004^{* * *}$ & $42.71^{\star \star \star}$ & $210.89^{* \star *}$ & $2938.36^{\star \star *}$ & $3.27^{\star}$ & $0.86^{\star * *}$ & $250.74^{* * *}$ & $101.72^{* \star \star}$ \\
\hline$P D^{\star} \operatorname{Var}^{\star} Y r$ & 6 & $0.001^{\mathrm{ns}}$ & $0.62^{\star *}$ & $3.08^{*}$ & $25.17^{\mathrm{ns}}$ & $1.03^{*}$ & $0.18^{\text {ns }}$ & $38.79^{\star *}$ & $10.98^{*}$ \\
\hline Error & 27 & 0.0004 & 1.77 & 8.76 & 152.75 & 0.55 & 0.20 & 34.13 & 7.01 \\
\hline Mean & & 0.04 & 5.64 & 12.53 & 70.81 & 9.36 & 5.47 & 36.57 & 24.84 \\
\hline CV (\%) & & 51.83 & 26.72 & 26.72 & 23.71 & 9.64 & 7.15 & 15.98 & 12.28 \\
\hline
\end{tabular}

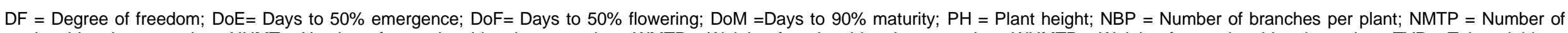

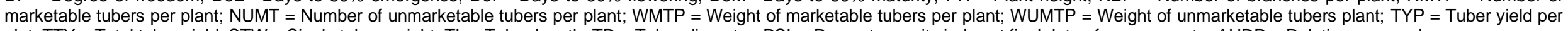

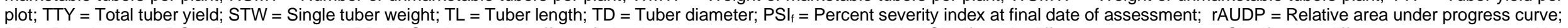

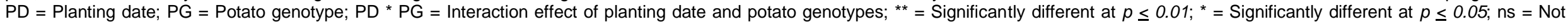
significant $(p>0.05) ; C V=$ Coefficient of variation $(\%)$. 
favor the spread of the late blight. Although there were higher accumulations of inocula in the surrounding fields obtained from the whole growing periods to cause an epidemic for potatoes, the effect was not as significant as the other planting dates. This circumstance might be due to the temperature, rainfall, and relative humidity progressively decreased afterward, from August, during the cultivating periods (Table 1). These unfavorable weather conditions might responsible for reducing the epidemic developments of late blight. As reported by Singh and Bhattachyra (1990), late blight development takes place between 8 and 48 hours under favorable environmental conditions when high rainfall ( $>20 \mathrm{~mm}$ per day), optimum temperature $\left(20\right.$ to $\left.25^{\circ} \mathrm{C}\right)$, and high relative humidity (70 to $90 \%$ ). In August, the disease symptoms appear later, which might be due to the less favorable environmental conditions, and the disease took longer days to higher epidemic development. Also, similar reports had noticed by Judelson and Blanco (2005), Muhinyuza et al. (2007), and Majid et al. (2008) who suggested that favorable environmental conditions for the development of late blight were the temperature of 15 to $20^{\circ} \mathrm{C}$, rainfall of more than $140 \mathrm{~mm}$ per month, and relative humidity of 70 to $90 \%$ during the growing season. During the late growing periods for each main plot and the subplot factors, the late blight was prevalent in all the experimental plots.

The results of the combined ANOVA of PSI and AUDPC for planting date and potato genotype are presented in Table 3. The highest PSIf $(44.70 \%)$ was recorded on the potato genotypes planted on 10th June. On the contrary, the lowest PSIf was noticed on lately (20th August) crop of potato genotypes. The minimum PSlf $(29.19 \%)$ values on 20th August could be due to the positive association and additive effect between planting dates and potato genotypes in affecting PSIf. The highest PSIf on the potato genotypes planted on 10th June might be due to favorable environmental conditions, optimum temperature, and high rainfall with high relative humidity for the disease development (Table 1). Postponement in planting date for the tested potato genotypes from 10th June to 20th August lowers PSl by $34.69 \%$ (Table 3). Then, the highest $(47.95 \%)$ and lowest PSI $(27.31 \%)$ were recorded on the potato genotypes local cultivar and Belete, respectively (Table 3). These might be due to the genetic makeup of the genotypes, weather conditions, and late planting during the growing period that disfavors the high severity, which in turn, can result in lower foliage and leaf area affected by late blight. In agreement with the present study, Abraham et al. (2015) and Getachew et al. (2019) observed that the potato genotypes planted at late planting dates had the lowest disease severity. However, early planting of the potato had the highest values of disease severity during the study periods in Ethiopia. In contrast to the current study, Bekele and Gebre-Medhin (2000), Singh and Pundhir (2012), and Gaire et al. (2014) reported that production of potato genotypes at early planting date had the lowest disease severity, followed by medium and late
Table 3. Late blight severity (\%) and area under disease progress curve (\%-days) as affected by potato genotypes at different planting dates at Chencha in Southern Ethiopia during 2018 and 2019 main cropping seasons.

\begin{tabular}{lcc}
\hline Treatments & PSI $_{\mathbf{f}}(\%)$ & rAUDPC \\
\hline Planting dates & & \\
At $10^{\text {th }}$ June (Early) & $44.70 \mathrm{a}$ & $29.31 \mathrm{a}$ \\
At $10^{\text {th }}$ July (Medium) & $35.82 \mathrm{~b}$ & $24.93 \mathrm{~b}$ \\
At $20^{\text {th }}$ August (Late) & $29.19 \mathrm{c}$ & $20.28 \mathrm{c}$ \\
Mean & 36.57 & 24.84 \\
& & \\
Potato genotypes & & \\
Belete & $27.31 \mathrm{a}$ & $19.37 \mathrm{a}$ \\
Gudanie & $32.45 \mathrm{~b}$ & $22.52 \mathrm{~b}$ \\
Jalenie & $38.58 \mathrm{c}$ & $26.16 \mathrm{c}$ \\
Local cultivar & $47.95 \mathrm{~d}$ & $31.32 \mathrm{~d}$ \\
Mean & 36.57 & 24.84 \\
\hline
\end{tabular}

Means in the same column followed by the same letters are not significantly different at $5 \%$ level of significance. $\mathrm{PSI}_{\mathrm{f}}=$ Percent severity index at final date of assessment; and rAUDP = Relative area under progress curve.

planting date during the study time worldwide, Ethiopia, India, and Nepal, respectively.

Similar to that of PSIf, the lowest AUDPC (20.28\%-days) was noted from the 20th August planting date than the other ones for the planted potato genotypes. Conversely, the highest AUDPC (29.31\%-days) was observed from the 10th June planting date for the planted potato genotypes. Potato genotypes planted on 20th August exhibited the lowest AUDPC could be due to the longest days to the appearance of late blight and the short days (112 DAP) to the crop physiologically matured as compared to other planting dates (Table 3). Also, this phenomenon might be because of minimum inoculums heaviness in the earlier planting days for 20th August, while early (10th June) planted potato genotypes might have a high spore load made in the environment in the neighborhood of the study areas. In addition, the highest AUDPC suggested that the highest late blight development on the evaluated potato genotypes cropped on the date of early 10th of June. This phenomenon might be due to the disease favored by the susceptibility of the genotype and favorable environmental conditions, and inocula loads come from short rainy season cultivation of potatoes during the growing year. The latter might responsible for high inoculum load and become the main factor for high epidemic development of late blight during early days of main season, long rainy season, cultivation of potato along with favorable weather conditions. This finding was supported by Razukas et al. (2008), Gaire et al. (2014), Abraham et al. (2015), and Getachew et al. (2019) who reported that the optimal conditions for late blight development and spread are high rainfall, relatively moist climate with nearly saturated relative humidity $(>70 \%)$ and optimum temperature (15 to 
Table 4. Mean values of phonological and growth related traits of four potato genotypes grown at three planting dates at Chencha in Southern Ethiopia during the 2018 and 2019 main cropping seasons.

\begin{tabular}{lccccc}
\hline Treatments & $\mathbf{5 0 \%} \mathbf{D o E}$ & $\mathbf{5 0} \% \mathbf{D o F}$ & $\mathbf{9 0 \%} \mathbf{D o M}$ & PH $\mathbf{( c m})$ & NBP \\
\hline Planting dates & & & & & \\
At $10^{\text {th }}$ June (Early) & $18.19 \mathrm{a}$ & $56.34 \mathrm{~b}$ & $85.31 \mathrm{a}$ & $37.64 \mathrm{~b}$ & $6.81 \mathrm{c}$ \\
At $10^{\text {th }}$ July (Medium) & $19.66 \mathrm{~b}$ & $54.22 \mathrm{a}$ & $86.09 \mathrm{a}$ & $38.00 \mathrm{~b}$ & $7.84 \mathrm{~b}$ \\
At $20^{\text {th }}$ August (Late) & $18.19 \mathrm{a}$ & $55.84 \mathrm{~b}$ & $88.28 \mathrm{~b}$ & $40.90 \mathrm{a}$ & $8.72 \mathrm{a}$ \\
Mean & 18.68 & 55.47 & 86.56 & 38.85 & 7.79 \\
& & & & \\
Potato genotypes & & & & \\
Belete & $19.13 \mathrm{~b}$ & $53.04 \mathrm{a}$ & $81.75 \mathrm{a}$ & $43.58 \mathrm{a}$ & $6.46 \mathrm{c}$ \\
Gudanie & $17.83 \mathrm{a}$ & $57.42 \mathrm{c}$ & $90.42 \mathrm{~d}$ & $45.70 \mathrm{a}$ & $6.71 \mathrm{c}$ \\
Jalenie & $18.88 \mathrm{ab}$ & $55.96 \mathrm{~b}$ & $86.04 \mathrm{~b}$ & $31.86 \mathrm{~b}$ & $8.00 \mathrm{~b}$ \\
Local cultivar & $18.88 \mathrm{ab}$ & $55.46 \mathrm{~b}$ & $88.04 \mathrm{c}$ & $34.25 \mathrm{~b}$ & $10.00 \mathrm{a}$ \\
Mean & 18.68 & 55.47 & 86.56 & 38.85 & 7.79 \\
\hline
\end{tabular}

Means in the same column followed by the same letters are not significantly different at $5 \%$ level of significant; DoE $=$ Days of $50 \%$ emergence; DoF= Days of 50\% flowering; DoM =Days of $90 \%$ maturity; $\mathrm{PH}=$ Plant height; and NBP = Number of branches per plant.

$\left.20^{\circ} \mathrm{C}\right)$. Regarding the potato genotypes, the highest and lowest AUDPC (31.32 and 19.37\%-days) were recorded on the potato genotype local cultivar and Belete, respectively. The high magnitude in the significant difference of AUDPC values among the evaluated potato genotypes might be due to their genotypic capability behavior to late blight responses. Previous researchers noticed that the highest AUDPC has occasioned from the highest disease development on the susceptible genotype of the crop that was affected by high disease pressure and has not managed with any of the management options (Campbell and Madden, 1990; Agrios, 2005).

\section{Phenological and growth related parameters}

The results obtained from combined ANOVA on phonological and growth-related traits of potato genotypes grown at three planting dates are presented in Table 4. The planting date of 10 th July showed the longest $50 \%$ DoE (19.66 days) than the other dates of planting for the evaluated potato genotypes. Similarly, the longest $50 \%$ DoF of 56.34 and 55.84 days was recorded from the evaluated potato genotypes planted on planting dates of 10th June and 20th August, respectively. The maximum of $90 \%$ DoM (88.28 days) for tested potato genotypes was recorded from the planting date of 20th August compared with the remaining planting dates. The minimum of $90 \%$ DoM of 85.31 and 86.09 days, which were statistically nonsignificant, were recorded for both planting dates of 10th June and July, respectively, for all planted potato genotypes. This implied that the earlier the disease appeared, the more the disease epidemics throughout the growing period depending on the conducive environmental condition and the availability, viability, and dispersibility of the pathogen. The reverse is true that is the late the disease came, the lower disease epidemics during the growing period or escaping of the plant from the high disease epidemics. Likewise, the tallest PH $(40.90 \mathrm{~cm})$ and the highest NBP (8.72) for the evaluated potato genotypes were recorded on the planting date of 20th August. The shortest $(37.64 \mathrm{~cm})$ and lowest NBP (6.81) were recorded from the planting date of 10th June for the evaluated potato genotypes, which is statistically similar to the value obtained from the tested potato genotypes planted at the planting date of 10th July (Table 4). A minimum of $50 \%$ DoE (17.83days) and a maximum of $50 \%$ DoF (57.42 days) and 90\% DoM (90.42 days) were recorded from the potato genotype Gudenie. The genotypes Gudenie and Belete exhibited the highest $\mathrm{PH}$ (45.70 and $43.58 \mathrm{~cm}$, respectively) and the lowest NBP (6.71 and 6.46, respectively) than the other genotypes (Table 4). This difference might have resulted from the variation in the genetic inheritance of the potato genotypes as well as the different planting dates that responded to the late blight pressure during the growing periods.

Potato planted on 20th August showed highest values for phenological and growth-related traits of potato, and this might be due to late planting and consequently escaping of potato genotypes from late blight attack with minimum severity and AUDPC as compared to other planting dates, whereas early planting (10th June) showed significantly lower values of phenological and growthrelated traits of potato due to less growth of the crop and early attack of plants by late blight and resulted in maximum severity and AUDPC. In contrast to the present study, Bekele and Gebre-Medhin (2000), Singh and Pundhir (2012), and Gaire et al. (2014) reported that early planted potato genotypes had shown the lowest disease pressure and highest growth and yield-related traits of potato even the highly susceptible potato genotypes exhibited the lowest disease severity and highest growth 
Table 5. Mean values of tuber yield and yield related traits of four potato genotypes grown at three planting dates at Chencha in Southern Ethiopia during the 2018 and 2019 main cropping seasons.

\begin{tabular}{|c|c|c|c|c|c|c|c|c|c|}
\hline Treatments & NMTP & NUMT & $\begin{array}{c}\text { WMTP } \\
(\mathrm{kg})\end{array}$ & $\begin{array}{c}\text { WUMTP } \\
(\mathrm{kg})\end{array}$ & $\begin{array}{l}\text { TYP } \\
(\mathrm{kg})\end{array}$ & $\begin{array}{c}\text { TTY } \\
\left(\mathrm{t} \mathrm{ha}^{-1}\right)\end{array}$ & $\begin{array}{l}\text { STW } \\
\text { (g) }\end{array}$ & $\begin{array}{c}\mathrm{TL} \\
(\mathrm{cm})\end{array}$ & $\begin{array}{c}\text { TD } \\
(\mathrm{cm})\end{array}$ \\
\hline \multicolumn{10}{|l|}{ Planting dates } \\
\hline At $10^{\text {th }}$ June (Early) & $5.94 a$ & $3.53 a$ & $0.26 a$ & $0.03 a$ & $5.51 \mathrm{a}$ & $12.25 a$ & $88.91 a$ & $7.34 b$ & $4.73 b$ \\
\hline At $10^{\text {th }}$ July (Medium) & $6.22 a$ & $3.94 a$ & $0.25 a$ & $0.03 a$ & $5.38 a$ & $11.95 a$ & $61.08 \mathrm{~b}$ & $10.42 a$ & $5.92 a$ \\
\hline At $20^{\text {th }}$ August (Late) & $5.69 a$ & $6.19 b$ & $0.26 a$ & $0.06 \mathrm{~b}$ & $6.03 a$ & $13.40 \mathrm{~b}$ & $62.43 \mathrm{~b}$ & $10.30 \mathrm{a}$ & $5.76 \mathrm{a}$ \\
\hline Mean & 5.95 & 4.55 & 0.26 & 0.04 & 5.64 & 12.53 & 70.81 & 9.36 & 5.47 \\
\hline \multicolumn{10}{|l|}{ Potato genotypes } \\
\hline Belete & $6.46 \mathrm{a}$ & $3.38 a$ & $0.28 b$ & $0.04 a$ & $6.18 \mathrm{~b}$ & $13.73 b$ & $69.87 \mathrm{~b}$ & $9.59 a b$ & $5.55 a$ \\
\hline Gudanie & $6.29 a$ & $3.17 a$ & $0.34 a$ & $0.03 a$ & $7.10 \mathrm{a}$ & $15.77 a$ & $87.20 \mathrm{a}$ & $10.20 \mathrm{a}$ & $5.58 \mathrm{a}$ \\
\hline Jalenie & $4.58 \mathrm{~b}$ & $4.08 a$ & $0.19 c$ & $0.03 a$ & $4.34 \mathrm{c}$ & $9.64 c$ & $71.11 \mathrm{~b}$ & $9.15 b$ & $5.47 a$ \\
\hline Local cultivar & $6.46 a$ & $7.58 \mathrm{~b}$ & $0.21 c$ & $0.06 \mathrm{~b}$ & $4.95 c$ & $10.99 c$ & $55.06 \mathrm{c}$ & $8.47 c$ & $5.28 \mathrm{a}$ \\
\hline Mean & 5.95 & 4.55 & 0.26 & 0.04 & 5.64 & 12.53 & 70.81 & 9.35 & 5.47 \\
\hline
\end{tabular}

Means in the same column followed by the same letters are not significantly different at $5 \%$ level of significance. NMTP = Number of marketable tubers per plant; NUMT $=$ Number of unmarketable tubers per plant; WMTP $=$ Weight of marketable tubers per plant; WUMTP $=$ Weight of unmarketable tubers per plant; TYP = Tuber yield per plot; TTY = Total tuber yield; STW = Single tuber weight; TL = Tuber length; and TD = Tuber diameter.

and yield-related traits, followed by medium and late planting dates during the study periods in Ethiopia, India, and Nepal, respectively. However, the results reported by the present study was supported by the work of Abraham et al. (2015) and Getachew et al. (2019) which revealed that potato genotypes planted on different planting dates within a given cropping season exhibited the highest values for phenological and growth-related traits of potato on late plating, followed by medium and early planting dates in Ethiopia.

\section{Tuber yield and yield related traits}

The mature tubers were harvested on an average dates of 169, 144, and 122 for 10th June, 10th July, and 20th August planting dates in the two cropping seasons, respectively. Analysis of variance for tuber yield and yieldrelated traits for potato genotypes planted on different planting dates are presented in Table 5 . No statistically significant difference was observed on NMTP, WMTP, and TYP of potato genotypes cropped on all planting dates. Maximum NUMT, WUMTP, and TTY of potato genotypes were recorded on the planting date of 20th August, while minimum values of the listed parameters were recorded on the other planting dates. The NUMT, WUMTP, and TTY are not statistically significantly different on planting dates of 10th June and July for the evaluated potato genotypes. The highest $(88.91 \mathrm{~g})$ and lowest $(61.08 \mathrm{~g})$ weights of STW were recorded on 10th June and July of planted potato genotypes, respectively. However, the lowest value obtained from the planting date of 10th July was not statistically different from 20th August. Then again, the longest TL and the widest TD were recorded on planting dates of 10th July and 20th August than 10th June for the evaluated potato genotypes, respectively (Table 5).

On the other hand, the highest NMTP (6.46) was obtained from the genotypes Belete and local cultivar, which are not significantly different from Gudenie for the evaluated planting dates. But, fewer NMTP (4.58) was obtained from the genotype Jallenie. No statistically significant differences was observed on NUMT and WUMTP on the genotypes Belete, Gudenie, and Jallenie, but local cultivar showed the highest NUMT $(7.58 \mathrm{~kg})$ and WUMTP $(0.06 \mathrm{~kg})$ as compared to other potato genotypes. The genotype Gudanie exhibited the highest WMTP (0.34 $\mathrm{kg})$, TYP $(7.10 \mathrm{~kg})$, TTY $(15.77 \mathrm{t})$, and STW $(87.20 \mathrm{~g})$ than the other potato genotypes. The longest TL was recorded on the genotype Gudanie $(10.20 \mathrm{~cm})$, in which no statistically significant difference was observed on the TD for the potato genotype Belete $(9.45 \mathrm{~cm})$ (Table 5). The average total tuber yield $\left(12.53 \mathrm{t} \mathrm{ha}^{-1}\right)$ obtained from the present study was much lower than the tuber yields obtained under research conditions even with the local cultivar by the releasing center, HARC. This phenomenon might have associated with the different planting dates or the studied agro-ecologies and the late blight pressure exerted by the potato genotypes to give a maximum yield of the genetic potential even under the pressure of the disease. As stated by Kleinkopf et al. (2003) and Mihovilovich et al. (2009), the potential values of tuber yield and yield-related traits that can be fruitfully produced by a plant differs with the genotype, physiological age of the seed, number of stems per hill and weather conditions during the beginning phase of growth. Variation in tuber yield and yield-related traits of the evaluated potato genotypes planted on the different planting dates might varied the levels of late blight severity and AUDPC due to 
the genetic background of the potato genotypes and change in the date of planting during the growing periods.

From the results obtained, it is can be concluded that planting of potato genotypes having a different response for late blight under the different planting dates played a significant role in lowering late blight pressure and increasing tuber yield and yield-related traits. This phenomenon could be accredited to their advantageous effects on tuber yield contributing parameters while producing unfavorable conditions for the epidemic development of late blight, disturb the biochemical processes and suppress high disease pressure. Maximum tuber yield and yield-related traits on 20th August could be due to late outbreaks of late blight and resulting in minimum severity and AUDPC with the highest vine mass production during the growing periods as compared to other planting dates along with the planted potato genotypes. Whereas early planting (10th June) showed significantly lower tuber yield and yield-related traits due to less growth of the foliage and early attack of plants by late blight and resulting in greater severity and AUDPC during the growing periods. However, the results from the present study were in contrast to the earliest reports by Bekele and Gebre-Medhin (2000), Singh and Pundhir (2012), and Gaire et al. (2014) who reported that early planting of potato genotypes had less epidemic development of late blight and increased yield and yield-related traits during the study periods in Ethiopia, India, and Nepal, respectively. The findings obtained from the current study were supported by the work of Abraham et al. (2015) and Getachew et al. (2019) who reported that producing of potato genotypes at late planting had the highest yield and yield-related traits, while early planting of the potato had lowest values of yield and yield-related traits during the study periods in Ethiopia.

\section{Conclusion}

The present study demonstrated that the phenological, growth, yield, and yield-related traits and disease parameters were significantly affected by the potato genotypes planted at different planting dates during the main cropping season. The potato genotypes exhibited different responses to late blight at each planting date. Production of the potato genotype Gudenie on planting date of 20th August showed minimum epidemic development of late blight, relatively lower disease severity, and AUDPC, with the highest marketable tuber yield as compared to the other potato genotypes and planting dates. The weather conditions played significant roles in the epidemic development of late blight during the growing periods. This phenomenon helps the potato genotypes to less responding and escaping from late blight influence during the late cropping season. Therefore, plantation of the genotype Gudenie on the planting date of 20th August proved to be relatively better in reducing late blight severity and AUDPC besides increasing production and productivity of tuber yields during the main cropping season, July to November. Thus, planting of potato on the date of 20th August could be suggest to the farming communities in the study areas and elsewhere with similar agro-ecological conditions for efficient and climate-smart management of potato late blight and optimization of tuber yield during the main cropping season to enhance sustainable potato production in the study areas and similar agro-ecological conditions in the country since the potato genotype was widely distributed throughout the country. Further studies on integrated management of late blight of potato should be continuing. Integrated management approaches are cultural practice, host resistance development and integration approaches, and fungicide applications in combinations or alone along with types, rates, and spray frequency with other options in the production systems.

\section{CONFLICT OF INTEREST}

The authors declared that they have no conflict of interest.

\section{ACKNOWLEDGMENTS}

This study had financially supported by the Southern Agricultural Research Institute and well acknowledged. We are very grateful to the staff of the Crop Research Work Process and the drivers of Arba Minch Agricultural Research Center for their facilitation and technical assistance during the study. The authors would like to forward special acknowledgments to the staff of the potato breeding program at Holeta Agricultural Research Center, Ethiopian Institute of Agricultural Research, for providing potato planting materials.

\section{REFERENCES}

Abraham, A., Getachew, G., \& Alemayehu, W. (2015). Determination of optimum planting date and resistant varieties of potato (Solanum tubersum) to the reaction of late blight (Phytophthora infestans) disease at Chencha, Southeastern Ethiopia. International Journal of Research in Agricultural Science, 4(6), 358-363.

Adane, H., Miranda, P., Meuwissen, M., Agajie, T., Willemien, J., Lommen, J., Alfons, O. L., Admasu, T., \& Struik, P. C. (2010). Analysis of seed potato systems in Ethiopia. American Journal of Potato Research, 87, 537-552.

Agrios, G. N. (2005). Plant pathology (5th edition). New York: Academic Press-Elsevier. 922 pp.

Arora, R. K. (1989). Distribution of healthy and late blight infected tubers in potato ridges. Indian Journal of Mycology and Plant Pathology, 19(2), 232-233.

Ayda, T. (2015). Effect of fungicides and resistant genotypes on severity of potato late blight [Phytophthora infestans (Mont.) de Bary] and yield and yield components at Haramaya, Eastern Ethiopia. Phd Thesis, Haramaya University, Haramaya, Ethiopia. 87pp. 
Bekele, K., \& Gebre-Medhin, W. (2000). Effect of planting date on late blight severity and tuber yields of different potato varieties. Pest Management Journal of Ethiopia, 4, 51-63.

Bourke, A. (1991). Potato blight in Europe in 1845: The scientific controversy (pp. 12-24). In: Lucas, J. A., Shattock, R. C., Shaw, D. S., \& Cooke, L. R. (eds). Phytophthora. Cambridge University Press, Cambridge.

Brent, K. J., \& Hollomon, D. W. (2007). Fungicide resistance in crop pathogens: How can it be managed? FRAC Monograph 1. 2nd edition. Crop Life International, Brussels. 55 pp.

Campbell, C. L., \& Madden, L. V. (1990). Temporal analysis of epidemics I. Description and comparison of disease progress curves. In: Introduction to Plant disease Epidemiology. John Wiley and Son. 532p.

Central Statistical Agency (CSA) (2018). Agricultural sample survey, 2017/2018 report on area and production of crops (Private peasant holdings, main season). Statistical Bulletin No. 446. Volume 5. Central Statistical Authority, Addis Ababa, Ethiopia. 60p.

de Barry, A. (1876). Researches into the nature of the potatofungus- Phytophthora infestans. Journal of Royal Agricultural and Society of England, 12, 239-268.

Food and Agriculture Organization of the United Nation (FAOSTAT) (2018). Agricultural data: Production and indices data crop primary. Retrieved 15 April 2020 from http://www.fao.org/faostat/en/\#data/QC/visualize.

Forbes, G. A, \& Jarvis, M. C. (1994). Host resistance for management of potato late blight (pp. 439-57). In: Zehnder, G., Jansson, R., Raman, K. V. (eds.). Advances in potato pest biology and management. American Phytopathological Society.

Gaire, S. P., Shrestha, S. M., \& Sharma A. B. P. (2014). Effect of planting dates and fungicides on potato late blight (Phytophthora Infestans (Mont.) De Bary) development and tuber yield in Chitwan, Nepal. International Journal of Research, 1(5), 148-160.

Getachew, G., Temam, H., Mashilla, D., \& Birhanu, B. (2018). Integrated management of tomato late blight [Phytophthora infestans (Mont.) de Bary] through host plant resistance and reduced frequency of fungicide in Arba Minch Areas, Southern Ethiopia. Journal of Biology, Agriculture and Healthcare, 8(9), 94-109.

Getachew, K. T, Fekadu, G. M., \& Gezahegn, B. Y. (2019). Effect of planting time and fungicide application frequency on severity of late blight (Phytophthora infestans), yield and yield components of potato (Solanum tuberosum L.) at Kulumsa, Southeast Ethiopia. African Journal of Agricultural Research, 14(33), 1815-1825.

Gomez, K. A., \& Gomez, A. A. (1984). Statistical procedures for agricultural research (2nd edition). John Wiley and Sons, Inc. New York, Chichester, Brisbane, Toronto and Singapore. 680 pp.

Green, M. B., Le Baron, H. M., \& Moberg, W. K. (1990). Managing resistance to agrochemicals: from fundamental research to practical strategies. American chemical society symposium series number 421. American Chemical Society. USA. 496 pp.

Guchi, E. (2015). Disease management practice on potato (Solanum tuberosum L.) in Ethiopia. World Journal of Agricultural Research, 3(1), 34-42.

Heinfnings, J. W. (1987). Late blight of potato (Phytophthora infestans). Technical information Bulletin 4. Lima. Peru. 25 pp.

Hijmans, R. J., Forbes, G. A., \& Walker, T. S. (2000). Estimating the global severity of potato late blight with GIS-linked disease forecast models. Plant Pathology, 49(6), 697-705

Hussain, S., Siddique, T., Saleem, M., Arshad, M., \& Khalid, A. (2009). Impact of pesticides on soil microbial diversity, enzymes, and biochemical reactions. Advances in Agronomy, 102, 159-200.

Judelson, H. S., \& Blanco, F. A. (2005). The spores of Phytophthora: weapons of the plant destroyer. Nature Reviews Microbiology, 3(1), 47-58.

Kassa, B., \& Hiskias, Y. (1996). Tuber yield loss assessments of potato cultivars with different levels of resistance to late blight (pp. 149-152). In: Bekele, E., Abdulahi, A., \& Yemane A. (eds.). Proceedings of the 3rd Annual Conference held on 18-19 May 1996, Crop Protection Society of Ethiopia, Addis Ababa, Ethiopia.

Kassa, B., Olanya, M., Tesfaye, A., Lemaga, B., \& Woldegiorgis, G. (2002). Economic implications of late blight management in tropical highlands of Ethiopia (p. 161). In: Lizarraga C (ed.). Late blight: Managing the global threat. Proceedings of the global initiative on late blight conference, Hanburg, Germany.

Kirk, W. W., Abu-El Samen, F. M., Muhinyuza, J. B., Hammerschmidt, R., Douches, D. S., Thill, C. A., Groza, H., \& Thompson, A. L. (2005). Evaluation of potato late blight management utilizing host plant resistance and reduced rates and frequencies of fungicide applications. Crop Protection, 24(11), 961-970.

Kleinkopf, G. E., Brandt, T. L., \& Olsen, N. (2003). Physiology of tuber bulking. In: Idaho Potato Conference on January 23.

Majid, R. F., Heather, L. M., \& Hamid, A. (2008). Genetics, genomics and breeding of late blight and early blight resistance in tomato. Critical Reviews in Plant Sciences, 27(2), 75-107.

McGrath, M. T., Menasha, S. R., \& LaMarsh, K. A. (2014). Evaluation of late blight resistant tomato cultivars on Long Island. Plant disease management reports, 8:V195. Cornell University and Cornell Cooprative Extention, LIHREC, SA 3019, NY 11901

Mekonen, S., Alemu, T., Kassa, B., \& Forbes, G. (2011). Evaluation of contact fungicide spray regimes for control of late blight (Phytophthora infestans) in southern Ethiopia using potato cultivars with different levels of host resistance. Tropical Plant Pathology, 36(1), 21-27.

Ministry of Agriculture (MoA) (2012). Animal and Plant Health Regulatory Directorate, Crop Variety Register Issue. No. 15, pp. 37-38. Addis Ababa, Ethiopia.

Ministry of Agriculture (MoA) (2013). Plant Variety Release, Protection and Seed Quality Control Directorate, Crop Variety Register Issue. No.1 6, pp.161-164. , Addis Abeba, Ethiopia.

Ministry of Agriculture and Natural Resources (MoANR) \& Ethiopian Agricultural Transformation Agency (EATA) (2016). Soil fertility status and fertilizer recommendation atlas of the Southern Nations, Nationalities and Peoples' Regional State, Ethiopia. Addis Ababa, Ethiopia. Pp. 198-253.

Mohammad, A., Mohammad, N., Safarzadeh, V., Peyman, S., \& Ali, S. (2016). Effect of plant density date and depth of cultivation on yield and yield components of potato planting in the chabahar. International Journal of Agronomy and Plant Production, 4(8), 1890-1897.

Muhinyuza, J. B., Jean-Claude, N., \& William, W. K. (2007). Susceptibility of commonly grown potato cultivars to potato late blight in Rwanda and control with fungicides. Ei-Minia Egypt. African Crop Science Conference Proceedings, 8, 835-840.

Razukas, A., Jundulas, J., \& Asakaviciute, R. (2008). Potato cultivars susceptibility to potato late blight (Phytopthtora infestans). Applied Ecology and Environmental Research, 6(1), 95-106. 
Roy, S., Singh, B. P., \& Bhattacharyya, S. K. (1991). Bio-control of late blight of potato. Phytopathology, 1, 17-18.

Satya, P. S., Traloki, S., Yadav, G. C., \& Shailendra, S. (2018). Influence of different planting dates on late blight incidence and yield of potato (Solanum tuberosum L.). International Journal of Current Microbiology and Applied science, 7, 3134-3137.

Schumann, G. L., \& D'Arcy, C. J. (2000). Late blight of potato and tomato. American Phytopathological Society.

Semira, N. (2016). Review on major potato disease and their management in Ethiopia. International Journal of Horticulture and Floriculture, 4(5), 239-246.

Singh, B. P., \& Bhattacharyya, S. K. (1990). Appearance, build up and spread of late blight in relation to source of inoculum. Indian Phytopathology, 43(3), 393-400.

Singh, V. K., \& Pundhir, V.S. (2012). Effect of date of planting on potato late blight development and tuber yield. Pantanagar Journal Research, 10(1), 31 - 35.

Statistical Analysis System (SAS) (2014). SAS/STATA user's guide for personal computers, version 9.3. SAS Institute Inc., Carry NC, USA.

Stone, A. (2014). Organic management of late blight of potato and tomato (Phytophthora infestans). Sustainable agriculture research and extention. Oregon State University, USA.

Tsedaley, B. (2014). Late blight of potato (Phytophthora infestans) biology, economic importance and its management approaches. Journal of Biology, Agriculture and Healthcare, 4(25), 215-225.
Tesfaye, A., Weldegiorgis, G., Kaguongo, W., Lemaga, B., \& Nigussie, D. (2013). Adoption and impact of potato production technologies in Oromia and Amhara regions. In: Weldegiorgis, G., Schulz, S., \& Berihun, B. (eds.). Seed potato tuber production and dissemination, experiences and challenges and prospects. Proceedings of the national workshop on seed potato production and dissemination, 12-14 March 2012. Bahir Dar, Ethiopia. Pp. 256-278.

Valbhav, K. S., \& Pundhir, V. S. (2012). Effect of date of planting on potato late blight development and tuber yield. Pantnagar Journal of Research, 10(1), 31 - 34.

Wastie, R. L. (1991). Phytophthora infestans, the cause of late blight of potato (Vol. 7. pp: 193-224). In: Ingram, D. S., \& Williams, D. S. (eds.). Breeding for resistance: Advances in plant pathology. Academic Press Ltd, London.

Wheeler, B. J. (1969). An Introduction to plant diseases. John Wiley and Sons, Inc. pp.ix + 374 pp.

Yoshida, K., Schuenemann, V. J., Cano, L. M., Pais, M., Mishra, B., Sharma, R., Lanz, C., Martin, F. N., Kamoun, S., Krause, J., \& Burbano, H. A. (2013). The rise and fall of the Phytophthora infestans lineage that triggered the Irish potato famine. Elife, 2, e00731. 